\title{
Erratum to: Management of bile duct injury after laparoscopic Cholecystectomy
}

Eur Surg (2011) 43/6: 342-350;

http://dx.doi.org/DOI 10.1007/s10353-011-0060-9

H. J. Mischinger, G. Bernhard, H. Cerwenka, H. Hauser, G. Werkgartner, P. Kornprat,

A. El Shabrawi, H. Bacher

Division of General Surgery, Department of Surgery, Medical University of Graz, Graz, Austria

Received November 9, 2011; accepted November 15, 2011

The name of the author G. Bernhard has been printed erroneously.

The false statement is corrected to G.A. Bernhardt. 